\title{
PENGARUH REKRUTMEN DAN KOMPETENSI GURU TERHADAP KINERJA GURU \\ (Studi pada Sekolah Dasar Negeri di Kecamatan Cengkareng Jakarta Barat)
}

\author{
Dwi Agustini ${ }^{1}$, Edi Mulyadi ${ }^{1}$ \& Jarnawi Afgani Dahlan ${ }^{2}$ \\ ${ }^{1}$ Program Pascasarjana UNIS Tangerang \\ ${ }^{1}$ Departemen Pendidikan Matematika UPI Bandung \\ Email: hjdwiagustini@gmail.com
}

\begin{abstract}
Abstrak
Penelitian ini bertujuan untuk mengetahui pengaruh rekrutmen terhadap kinerja guru. Mengetahui pengaruh kompetensi guruterhadap kinerja guru. Mengetahui pengaruh rerkutmen dan kompetensi guru secara bersama sama terhadap kinerja guru. Penelitian ini menggunakan multiple stage sample. Sampel berukuran 36 responden (kepela sekolah) berasal dari 2 SDN sebagai populasi terjangkau yang diambil dari populasi target berjumlah 80 SDN di Kecamatan Cengkareng Jakarta Barat. Pengumpulan data dilaksanakan dengan penyebaran angket. Analisis data dilakukan dengan metode survey dengan pendekatan kuantitatif teknik regresi dan korelasi. Penelitian ini dilaksanakan dari bulan April sampai dengan Juli 2017. Hasil penelitian menunjukkan: (1)Terjadi pengaruh yang kurang kuat antara rekrutmen dengan kinerja guru. Hal ini dapat dibuktikan dengan memperhatikan nilai $\mathrm{r}=0,146$. (2)Terjadi pengaruh yang kuat antara kompetensi guru dengan kinerja guru. Hal ini dapat dibuktikan dengan memperhatikan nilai $r=0,405$ (3) Terjadi pengaruh yang kuat atara rekrutmen dan kompetensi guru secara bersama sama dengankinerja guru. Hal ini dapat dibutikan dari nilai $r=0,426$. Berdasarkan data diatas dapat simpulkan bahwa rekrutmen dan kompetensi guru baik secara sendiri maupun secara bersama-sama memberikan sumbanagan yang berarti terhadap kinerja guru di Seklah Dasar Negeri Cengkareng Jarta Barat.
\end{abstract}

Kata Kunci: Rekrutmen. Kompetensi Guru, dan Kinerja Guru

\section{A. Pendahuluan}

Sumber daya manusia yang berkualitas hanya dapat dicapai melalui proses pendidikan yang berkualitas. Ini berarti bahwa menciptakan proses pendidikan yang berkualitas merupakan cita-cita tertinggi sebagai bagian yang tidak terpisahkan dari tujuan nasional untuk mencerdaskan kehidupan bangsa Sekolah merupakan sebagai suatu institusi atau lembaga pendidikan yang merupakan sarana untuk melaksanakan proses pendidikan. Sekolah bukan hanya sebagai tempat berkumpul antara guru dan siswa melainkan suatu sistem yang kompleks dan dinamis.Selain itu juga sekolah merupakan suatu wadah untuk menciptakan sosok sumber daya manusia yang berpendidikan sesuai dengan visi, misi, tujuan dan target yang telah direncanakan seolah tersebut.
Manajemen diperlukan agar pengelolaan pendidikan di sekolah terarah melalui pengembangan visi, misi dan tujuan yang jelas. Bisa saja sekolah yang memiliki guru yang berkualitas, sarana dan prasarana yang memadai, siswa yang kualitasnya diatas rata-rata tetapi gagal adalam mewujudkan lulusan yang berkualitas. Hal ini bisa saja disebabkan karena tidak adanya visi, misi dan tujuan yang jelas, disamping kurangnya koordinasi tim kerja dengan pihak manajemen sekolah. Tenaga pendidik dan kependidikan merupakan salah satu unsur terpenting dalam meningkatkan mutu pendidikan.

Tenaga kependidikan adalah anggota masyarakat yang mengabdikan diri dan diangkat untuk menunjang penyelenggaraan pendidikan, yang meliputi pengelola satuan pendidikan, 
penilik, pamong belajar, pengawas, peneliti, pengembang,pustakawan, laboran dan teknisi sumber belajar.Pendidik adalah tenaga kependidikan yang berkualifikasi sebagai guru, dosen, konselor, pamong belajar, widyaiswara, tutor, instruktur, fasilitator, dan sebutan lain sesuai dengan kekhususannya, serta berpartisipasi, dalam penyelenggaraan pendidikan. Melihat peran tenaga pendidik dan kependidikan begitu penting maka perlu adanya strategi rekrutmen (penarikan) yang bisa menghasilkan calon-calon tenaga pendidik dan kependidikan yang profesional. Rekrutmen pendidik dan kependidikan adalah seperangkat kegiatan dan proses yang dipergunakan untuk memperoleh sejumlah orang yang bermutu pada tempat dan waktu yang tepat sesuai dengan ketentuan hukum yang berlaku sehingga orang dan sekolah dapat saling menyeleksi berdasarkan kepentingan terbaik masingmasing dalam jangka panjang maupun jangka pendek.

Pelaksanaan rekrutmen yang baik diharapkan sekolah mendapat tenaga pendidik dan kependidikan yang sesuai dengan kualifikasi yang ditetapkan sekolah, karena di dalam keberlangsungan kegiatan sekolah unsur manusia merupakan unsur yang sangat penting, karena kelancaran jalannya pelaksanaan program sekolah sangat ditentukan oleh orang-orang yang terlibat di dalamnya. bagaimana pun lengkap dan modernnya fasilitas gedung, perlengkapan, alat kerja, metode dan dukungan masyarakat, akan tetapi apabila orang-orang yang ada di dalamnya kurang berkompeten terhadap setiap tugas yang diembannya, maka akan sangat sulit dalam mencapai tujuan pendidikan yang diharapkan. Guru merupakan jabatan atau profesi yang memerlukan keahlian khusus sebagai pendidik. Pekerjaan ini tidak bisa dilakukan oleh orang yang tidak memiliki keahlian untuk melakukan kegiatan atau pekerjaan sebagai guru. Dengan kata lain guru secara sederhana adalah orang yang memberikan ilmu pengetahuan kepada anak didik. Karena tugasnya itulah, guru dapat menambah kewibawaannya dan keberadaan guru sangat diperluk

Kompetensi guru merupakan seperangkat tindakan intelegen penuh tanggung jawab yang harus dimiliki seseorang guru sebagai syarat untuk dianggap mampu melaksanakan tugastugas dalam bidang tertentu yang indikatornya meliputi; (1) keilmuan, (2) sosial, (3) spiritual yang secara kaffah membentuk kompetensi guru yang mencakup penguatan materi, (4) pemahaman terhadap peserta didik, (5) pembelajaran yang mendidik, (6) pengembangan pribadi.

Berdasarkan Peraturan Menteri Pendidikan Nasional Nomor 16 Tahun 2007 tentang Standar kualifikasi Akademik dan kompetensi Guru di jelaskan bahwa standar kompetensi guru dikembangkan secara utuh dari empat kompetensi utama yaitu, kompetensi pedagogiik, kompetensi kepribadian, kompetensi sosial dan kompetensi professional. Ke empat kompetensi tersebut berintegrasi dalam kinerja guru.

Kinerja secara formal didefinisikan sebagai nilai sekumpulan perilaku pekerja yang menyumbangkan, baik positif atau negatif terhadap pencapaian tujuan organisasi. Mengacu pada kedua definisi ini, maka kinerja guru dapat diartikan sebagai kompetensi, nilai dan sekumpulan perilaku guru yang menyumbangkan dampak, baik positif atau negative terhadap pelaksanaan tugas pokok guru. Berdasakan fenomena di atas, maka perlu adanya kesadaran dari lembaga sekolah dalam perekrutan tenaga pendidik dan kepen- didikan bahwa perlu ada tindak lanjut dalam meningkatkan kinerja guru secara berkelanjutan dengan cara rekrutmen dan kompetensi yang linier dengan tugas.

Memperhatikan persoalan diatas, dianggap signifikan antara Rekrutmen dan kompetensi dalam melakukan pengajaran terhadap kinerja guru. Oleh sebab itu penulis tertarik untuk melakukan penelitian tentang Pengaruh Rekrutmen 
dan Kompetensi Guru Terhadap Kinerja Guru Pada Sekolah Dasar Negeri Di Kecamatan Cengkareng JakartaBarat.

\section{Kajian Literatur \\ Rekrutmen}

Castetter (dikutip Mulyasa 2005:55) mengartikan rekrutmen sebagai “ Suatu rangkaian kegiatan dalam pengelolaan ketenagaan yang dirancang untuk mem- peroleh tenaga dalam jumlah dan mutu sekolah yang dibutuhkan untuk melaksanakan tugas-tugas yang ada dalam sistem sekolah " Sebagai bagian dari pengelolaan ketenagaan, rekrutmen terkait dengan fungsi-fungsi ketenagaan yang lain. Ia mendukung dan didukung oleh fungsi ketenagaan yang lain dalam satu kesatuan fungsi yang harmonis.

Paparan di atas memperlihatkan dengan jelas bahwa rekrutmen terlaksana atas dukungan rencana yang dibuat sebelumnya. Dukungan rekrutmen terhadap fungsi ketenagaan lain mensyaratkan rekrutmen terjadi dalam situasi kualifikasi tertentu.

Menurut Dunnette (1998:401), teori rekrutmen terdiri dari tiga hal yaitu, process variable, independent variable, dan dependent variable. Ketiga variabel ini akan saling berhubungan dan mempengaruhi dari proses rekrutmen. Process variable adalah suatu mekanisme dalam psikologi atau mekanisme lingkungan yang dianggap sebagai hal yang menentukan hasil dari bermacammacam metode rekrutmen.Independent variable adalah suatu gambaran umum tentang praktik rekrutmen. Adapun, dependent variable adalah hasil dari proses rekrutmen tersebut. Setiap variabel-variabel tersebut pun masih dibagi menjadi beberapa elemen. Kualifikasi itu mengacu kepada setiap kegiatan yang terjadi dalam proses rekrutmen. Kualitas kegiatan dalam proses rekrutmen itulah yang menentukan kualitas rekrutmen, dan pada gilirannya kualitas rekrutmen mempengaruhi kualitas fungsi-fungsi lain terutama yang berhubungan langsung dengan rekrutmen seperti seleksi dengan pembinaan. Perekrutan tenaga pendidik dan kependidikan dapat ditentukan dari berbagai sumber. Prioritas utama dititik beratkan pada orientasi manejemen tenaga pendidik dan kependidikan berdasarkan pertimbangan dan kebijakan yang diambil. Masa depan sekolah salah satunya bergantung pada kelihaian manajemen SDM dalam menentukan dan memilih tenaga pendidik dan kependidikan yang cakap, sesuai dengan motif orientasi sekolah. Secara garis besar penentuan sumber tenaga pendidik dan kependidikan dapat dilakukan dengan dua sumber, yaitu perekrutan dari internal dan perekrutan dari eksternal sekolah.

Rekrutmen secara internal, artinya lembaga yang membutuhkan tenaga kerja hanya perlu membuat pengumuman mengenai lowongan pekerjaan untuk posisi yang kosong tersebut. Informasi tersebut akan menyebar dari pegawai yang satukepada pegawai yang lain atau bisa juga terjadi mutasi beberapa pegawai dari suatu posisi yang kosong tersebut melalui rapat internal lembaga.

Sumber eksternal adalah karyawan/ pegawai yang akan mengisi jabatan yang lowong dilakukan penarikan dari sumber-sumber tenaga kerja di luar perusahaan, antara lain berasal dari:(1) Media cetak (koran). (2) Media elektronik (Radio dan Televisi. (3) Media Sosial dll.

Berdasarkan paparan dari ahli di atas bahwa sintesa rekrutmen dalam penelitian ini adalah sebagai aktivitas manajeman sekolah yang mengupayakan didapatkan- nnya seorang atau lebih guru yang betul-betul potensial untuk menjadi guru kelas, guru mata pelajaran atau guru lainnya dalam rangka memenuhi kebutuhan guru di sekolah dasar yang bersangkutanmelalui serangkaian proses yang digunakan secara legal untuk memperoleh sejumlah orang-orang yang berkualitas.

\section{Kompetensi Guru}


Menurut UU No.14 tahun 2005 tentang Guru dan Dosen Pasal 1 Ayat 10, disebut-kan:Kompetensi adalah seperangkat penge- tahuan, ketrampilan, dan perilaku yang harus dimiliki, dihayati, dan dikuasai oleh guru atau dosen dalam melaksanakan tugas keprofesionalan. Menurut Muhibbin Syah kompetensi berarti the state of being legally competent or qualified yaitu keadaan berwenang atau memenuhi syarat menurut ketentuan hukum. Adapun kompetensi guru (teacher competency) is the ability of a teacher to responsibility perform his or her duties appropriately. Kompetensi guru merupakan kemampuan seseorang guru dalam melaksanakan kewajiban-kewajiban secara bertanggung jawab dan layak. Dengan gambaran pengertian tersebut, dapatlah disimpulkan bahwa kompetensi merupakan kemampuan dan kewenangan guru dalam melaksanakan profesi keguruannya.

Dari beberapa penjelasan mengenai kompetensi dapat ditarik kesimpulan bahwa kompetensi merupakan kemampuan seseorang yang meliputi pengetahuan, keterampilan, dan sikap, yang dapat diwujudkan dalam hasil kerja nyata yang bermanfaat bagi diri dan lingkungannya. Ketiga aspek kemampuan ini saling terkait dan mempengaruhi satu sama lain. Kondisi fisik dan mental serta spiritual seseorang besar pengaruhnya terhadap produktivitas kerja seseorang, maka tiga aspek ini harus dijaga pula sesuai standar yang disepakati.

Guru bisa mempunyai kinerja yang bagus jika guru tersebut bisa profesional dalam menjalankan tugasnya maka Untuk mencapai guru yang profesional tersebut maka Badan independen National Council for Accreditation of Teacher Education (Tilaar, 2006). Menentukan 10 syarat dari program pendidikan professional guru sebagai berikut :

1) Perkembangan dan desain kurikulum.

2) Perencanaan dan manajemen institusional

3) Evaluasi dan asessmen mengenai kemajuan belajar peserta didik.
4) Supervisi kelas dan manajemen tingkah laku peserta didik.

5) Penguasaan teknologi instruksionsl.

6) Perkembangan peserta didik dan cara belajarnya.

7) Kesulitan-kesulitan di dalam belajar (learner exceptionality)

8) Peraturan-peraturan pendidikan di sekolah.

9) Pendidikan multikultural dan globalisasi.

10) Dasar-dasar sosial, sejarah, dan

filsafat pendidikan

Guru memiliki tugas dan peran yang sangat strategis dalam dunia pendidikan. Menurut Mulyasa dikutip bukunya " Menjadi Guru Profesiona:,2008 di jelaskan bahwa peran guru dalam pembelajaran adalah banyak peranan yang diperlukan .dari guru sebagai pendidik, atau siapa saja yang menerjunkan diri menjadi guru. Semua peranan yang diharapkan dari guru seperti diuraikan di bawah ini: (1) Korektor ,(2) Inspirator, (3) informator, (4) Organisator (5) Motivator, (6) Inisiator, (7) Fasilitator, Demonstrator, (9) Supervisor, (10) Evaluator. Berdasar dari pendapat para ahli penulis dapat menyimpulkan, Kompetensi guru seperangkat tindakan intelegen penuh tanggung jawab yang harus dimiliki seseorang guru sebagai syarat untuk dianggap mampu melaksanakan tugastugas dalam bidang tertentu yang meliputi keilmuan, sosial, spiritual yang secara kaffah membentuk kompetensi guru yang mencakup penguatan materi, pemahaman terhadap peserta didik, pembelajaran yang mendidik, pengembangan pribadi dan profesionalisme

\section{Kinerja Guru}

Menurut (Daoed Yoesoef (1980)) menyatakan bahwa seorang guru mempunyai tiga tugas pokok yaitu tugas profesional, tugas manusiawi, dan tugas kemasyarakatan ( civic mission ). Jika dikaitkan pembahasan tentang kebudayaan, maka tugas pertama berkaitan dengan logika dan estetika, tugas kedua 
dan ketiga berkaitan dengan etika. Tugastugas profesional dari seorang guru yaitu meneruskan atau transmisi ilmu pengetahuan, keterampilan dan nilai-nilai lain yang sejenis yang belum diketahui anak dan seharusnya diketahui oleh anak. Tugas manusiawi adalah tugas-tugas membantu anak didik agar dapat memenuhi tugas-tugas utama dan manusia kelak dengan sebaik-baiknya. Tugas-tugas manusiawi itu adalah transformasi diri, identifikasi diri sendiri dan pengertian tentang diri sendiri.

Guru yang efektif menurut james $\mathrm{H}$ stronge (2007 : 201) adalah guru yang selalu memperhatikan proses belajar pribadinya secara berkelanjutan dan mereflesikan sluruh elemen kinerjanya dalam usahanya untuk meningkat secara berkelanjutan.Guru yang efektif, pengembangan dengan pengembangan sekolah dan pengembangan pendidikan secara keseluruhan, sehingga kontribusi profesionalnya berfokus pada praktik pembelajaran yang dilakukannya di kelas maupun di lingkungan sekolah.

Menurut Prawirosentoso, kinerja performance adalah usaha yang dilakukan dari hasil kerja yang dapat dicapai oleh seseorang atau sekelompok orang dalam suatu organisasi sesuai dengan wewenang dan tanggung jawab masing-masing dalam rangka mencapai tujuan organisasi bersangkutan secara legal, tidak melanggar hukum dan sesuai dengan moral dan etika. (prawirosentoso, 2000:1).

Kinerja atau prestasi kerja (performance) dapat diartikan sebagai pencapaian hasil kerja sesuai dengan aturan dan standar yang berlaku pada masing-masing organisasi dalam hal ini sekolah.Uraian tersebut di atas mencerminkan bahwa jabatan guru adalah "profesi" Profesi yang dimaksud adalah keahliannya dalam bidang pendidikan. Ia bekerja atau melakukan pekerjaan mendidik orang-orang yang menjadi peserta didiknya. Yang tidak dapat dilakukan oleh sembarang orang di luar bidangnya pekerjaan ini cukup berat.
Karena meliputi tiga komponen, yakni mendidik, mengajar dan melatih. Mendidik berarti meneruskan dan mengembangkan nilai-nilai hidup.

Mengajar dapat diartikan sebagai upaya meneruskan dan mengembangkan ilmu pengetahuan. Sedangkan melatih adalah mengembangkan keterampilanketerampilan pada peserta didik. Service learning increases youth's civic knowledge and political engagement, strengthens openness to diversity and difference, and promotes better and deeper understanding of course content (Astin \& Sax, 1998; Bell et al., in press; Billig et al., 2005; Chang, 2002). Guru harus bisa memberikan sebuah service yang bagus untuk meningkatkan kemampuan dan pengetahuan peserta didiknya.

Kinerja lebih berkonotasi pada sejauh mana seseorang melakukan aktifitas baik yang berkenaan dengan tugas dan kewajiban yang sesuai dengan tingkat kompetensi yang dikuasainya atau dengan kata lain kinerja sebagai perilaku lebih banyak dimotori dan koordinasikan oleh sejumlah pengetahuan maupun informasi yang dikuasai seseorang dalam melaksanakan kegiatan sesuai dengan tuntutan tugasnya.

Berdasarkan pendapat ahli penulis menyimpulkan, kinerja guru merupakan seperangkat nilai dan sekumpulan perilaku yang mencakup pengetahuan, sikap dan keterampilan yang menyumbangkan, baik positif atau negatif terhadap pelaksanaan tugas pokok guru dalam rangka pencapaian tujuan pembelajaran, dengan indikator (1) pengetahuan professional (2) perencanaan pembelajaran, penyampaian pembelajaran, (4) penilaian pembelajaran (5) lingkungan belajar (6) profesionalisme dan (7) perkembangan belajar siswa.

\section{B. Metodologi}

Penelitian menggunakan metode survey dengan pendekatan kuantitatif teknik korelasi dan regresi. Metode survei adalah penelitian yang mengambil sampel 
dari satu populasi dan menggunakan koesioner sebagai alat pengumpul data. Adapun data yang akan dikumpulkan dari responden adalah data yang terkait dengan variabel penelitian ini yaitu, variabel rekrutmen $\left(\mathrm{X}_{1}\right)$, variabel kompetensi guru $\left(\mathrm{X}_{2}\right)$ sebagai variabel bebas dan variabel Kinerja Guru (Y) sebagai terikat.

Populasi target dalam penelitian ini adalah kepala sekolah SDN yang ada di Kecamatan cengkareng Jakarta Barat. Adapun yang dijadikan populasi terjangkau pada penelitian ini adalah SDN yang ada di dua Kelurahan Kecamatan Cengkareng , Yang tiap kelurahan memiliki sekolah inti dan sekolah imbas

Dalam penelititan ini menggunakan teknik multiple stage saple. Besar sampel adalah 31 responden (kepala sekolah) yang diwakili oleh: (1) Kel. Cengkareng Timur berjumlah 21 SDN ( 4 SDN Inti dan 17 SDN Imbas ) (2) Kel. Kapuk berjumlah 15 SDN ( 4 SDN Inti dan 11 SDN Imbas )

Pengumpulkan data menggunakan metode koesioner ( angket), yaitu dengan memberikan daftar pertanyaan/pernyataan kepada responden dengan harapan memberikan respon atas daftar pertanyaan/ pernyataan tersebut. Daftar pertanyaan/ pernyataan berupa serangkaian terstruktur dan materinya berhubungan dengan unsurunsur yang menyangkut dengan pengaruh rekrutmen dan kompetensi guru dan kinerja guru.Penilaian jawaban responden dilakukan berdasakan skala Likert dengan Rentang skor 1-5.

Pengujian anaisis data dilakukan
secara bertahap sesuai dengan
ketententuan yang dipersyaratkan yaitu; diawali dengan uji analisis deskripsi, dilanjutkan dengan uji normalitas dan uji multikolonieritas untuk memenuhi uji prasyarat. Uji hipotesis menggunakan uji regresi parsial, uji regresi berganda dan uji korelasi.

\section{Pembahasan Hasil Penelitian}

Pegujian hipotesi 1 adalah untuk mengetahui pengaruh rekrutmen terhadap kinerja guru. Kinerja guru merupakan seperangkat nilai dan sekumpulan perilaku yang mencakup pengetahuan, sikap dan keterampilan yang menyumbangkan, baik positif atau negative terhadap pelaksanaan tugas pokok guru dalam rangka pencapaian tujuan pembelajaran, Perlu diketahui rekrutmen adalah sebagai aktivitas manajeman sekolah dasar yang mengupayakan didapatkannnya seorang atau lebih guru yang betul-betul potensial untuk menjadi guru kelas, guru mata pelajaran atau guru lainnya dalam rangka memenuhi kebutuhan guru di sekolah dasar yang bersangkutan melalui serangkaian proses yang digunakan secara legal untuk memperoleh sejumlah orangorang yang berkualitas. Rekrutmen yang sesuai dengan kemampuannya dapat meningkatkan mutu dari pekerjaan tersebut, menjadi sangat penting penempatan kerja yang tepat dan bijak juga menjadi acuan bagi kepala sekolah untuk memutuskan layak atau tidaknya guru itu ditempatkan. Dari pemikiran di atas patut diduga terdapat pengaruh antara rekrutmen dengan kinerja guru.

Dari hasil analisis data yang berasal dari angket rekrutmen dan setelah dilakukan uji regresiparsial pada tabel Coeficient $^{\mathrm{a}}$ didapatkan angka sig $=0.411$ (Sig > 0.05). Keriteria yang diambil jika sig $<0,05$ hipotesi H0 diterima. Berdasarkan asumsi dan kriteria di atas menunjukkan bahwa variable rekrutmen member berpengaruh positif terhaikan pengaruh positif tidak signifikan terhadap kinerja guru. Jika disandingkan dengan hasil uji krelasi parsial maka didapat koefien korelasi (r) sebesar 0,146. Inni menunjukkan bahwa rekrutmen dapat memberikan kontribusi sebesar 14,6\% untuk kinerja guru suatu anggka yang belum signifikan.

Menurut Muhaimin, kompetensi adalah seperangkat tindakan intelegen penuh tanggung jawab yang harus dimiliki seseorang sebagai syarat untuk dianggap mampu melaksanakan tugas-tugas dalam bidang tertentu. Sifat intelegen harus ditunjukan sebagai kemahiran, ketetapan, 
dan keberhasilan bertindak. Sifat tanggung jawab harus ditunjukan sebagai kebenaran tindakan baik dipandang dari sudut ilmu pengetahuan, teknologi maupun etika.

Pengujian hipotesis 2 adalah untuk mengetahui pengaruh kompetensi guru terhadap kinerja guru. Kompetensi guru adalah pengetahuan, keterampilan dan kemampuan yang dikuasai oleh seseorang yang telah menjadi bagian dari dirinya, sehingga ia dapat melakukan tugas profesi guru dengan mengutmakan perilaku kognitif, afektif dan psikomotorik dengan sebaik-baiknya terhadap peseta didiknya.

Dari hasil analisis data angket kompetensi guru dikaitkan dengan melalui uji regresi parsial didapat angka sig $=0,016$ atau Sig $<0.05$. berarti hipotesis Ho ditolak. Hal ini menunjukkan bahwa variabel kompetensi guru berpengaruh positif signifikan terhadap kinerja guru.

Jika dilihat dari hasil uji korelasi parsial didapat koefesien korelasi (r) 0,405. Hal ini menunjukkan bahwa variabel kompetensi guru memberi knteribusi sebesar 40,5\% suatu angka yang sukup besar. Dan 59,5\% berasal dari faktor lain yang tidak diteliti.

Pengujian hipotesis 3 adalah untuk mengetahui pengaruh rekrutmen dan kompetensi guru secara bersama terhadap kinerja guru. Salah satu sumber perekrutan tenaga pendidik dan kependidikan di sekolah adalah melalui rekrutmen secara internal, artinya lembaga yang membutuhkan tenaga kerja hanya perlu membuat pengumuman mengenai lowongan pekerjaan untuk posisi yang kosong tersebut. Rekrutmen dapat terlaksana atas dukungan rencana yang dibuat sebelumnya. Dukungan rekrutmen terhadap fungsi ketenagaan lain mempersyaratkan rekrut- men terjadi dalam kualifikasi tertentu.Kualifikasi itu mengacu kepada setiap kegiatan yang terjadi dalam proses rekrutmen. Kualitas kegiatan dalam proses rekrutmen itulah yang menentukan kualitas rekrutmen, dan pada gilirannya kualitas rekrutmen mempengaruhi kualitas fungsi-fungsi lain terutama yang berhubungan langsung dengan rekrutmen seperti seleksi dengan pembinaan. Rekrutmen yang terseleksi dengan baik dan berkalitas akan mendapatkan orang (guru) terbaik Sedangkan Kompetensi guru adalah kemampuan kerja personel dalam bidang pembelajaran, pengetahuan, keterampilan, perangai/ sifat dan konsep diri bagi peserta didik agar melahirkan generasi berilmu dan berkarakter.Berdasar pada pemikiran itu patut diduga terdapat pengaruh antara rekrutmen dan kompetensi dengan kinerja guru.

Dari hasil uji regresi berganda didapat angka sig $=0,037$ atau sig $<0.05$ yang berarti Ho ditolak.Ini membuktikan bahwa terdapat pengaruh signifikan rekrutmen, dan kompetensi guru, secara bersama-sama terhadap kinerja guru. Jika dikonfirmasikan dengan hasil uji korelasi berganda dengan koefisien korelas $(\mathrm{R})=$ 0,426 , ini menunjukkan bahwa rekrutmen dan kompetensi guru secara bersama-sama memberikan kontribusi $42,6 \%$ kepada kinerja guru. Dan $57,4 \%$ berasal dari faktor lain yang tidak ditelti.

\section{Kesimpulan Dan Saran}

Kesimpulan dari hasil penelitian ini adalah: (1) Terjadi hubungan yang kurang kuat antara rekrutmen dengan kinerja guru. Hal ini dapat dibuktikan dengan memperhatikan nilai $r=0,146$. (2) Terjadi hubungan yang kuat antara kompetensi guru dengan kinerja guru. Hal ini dapat dibuktikan dengan memperhatikan nilai $r$ $=0,405$ (3) Terjadi hubungan yang kuat atara rekrutmen dan kompetensi guru secara bersama sama dengankinerja guru. Hal ini dapat dibuktikan dari nilai $\mathrm{r}=$ 0,426.Berdasarkan data diatas dapat simpulkan bahwa rekrutmen dan kompetensi guru baik secara sendiri maupun secara bersama-sama memberikan sumbangan yang berarti terhadap kinerja guru Sekolah Dasar Negeri di kecamatan Cengkareng Jakarta Barat.

Adapun saran yang penulis dapat berikan adalah sebagai berikut: 
1. Dalam kesimpulan di atas dikekmukan adanya hubungan yang kurang kuat antara rekrutmen dan kinerja guru, dengan itu maka diharapkan kepada Kepala Sekolah Dasar Negeri di Kecamatan Cengkareng lebih memperhatikan dan memperbaiki proses rekrutmen.

2. Guru diharapkan selalu menjaga dan meningkatkan kompetensi dalam mempertahankan dan meningkatkan kinerja guru.

3. Guru menyadari bahwa dalam upayanya untuk selalu meningkatkan kompetesi guru, maka seorang guru tdak pernah berhenti utuk belajar dan terus belajar.

4. Kepala Sekolah sebagai pemimpin perlu lebih mengaktifkan kegiatan supervisi sehingga dapat memotivasi para guru dalam meningkatkan kompetensi dan kinerja guru di SDN kecamatan Cengkareng Jakarta Barat

\section{E. Daftar Pustaka}

Dunnette, M.D. \& Hough, L.M. (Eds.). (1998). Handbook of Industrial and Organizational Psychology: Vol. 2. (2nd ed.). Mumbai: Jaico Publishing House.
Ma'mur

Asmani

Jamal. (2009).Manajemen Pengelolaan Dan Kepemimpinan Pendidikan Profesional, ( Yogyakarta : Diva Press

Muhibbin Syah. (1995). Psikologi Pendidikan Suatu Pendekatan Baru,PT. Remaja Rosda Karya, Bandung, 1995, hlm. 230.

Mulyasa, E. (2005). Manajemen Berbasis Sekolah. (Bandung: Remaja Rosdakarya)

Sujana, N. (1998). Dasar-dasar proses belajarmengajar, Bandung, Suara Baru.

Nazir, M. (2009). Metode Penelitian. Jakarta: Galia Indonesia.

Redyanti, Puti. 2009. Analisis Model Pelaksanaan Rekrutmen dan Seleksi Karyawan. Pt UNITEX Tbk. Naskah tidak diterbitkan.

http:/htt/:edukasi.kompasiana.com/2011/0

2/17/peran-kinerja-gurudalameningkatkan-kwalitaspendidikan-ditinjau-dari-input-prosesdan-output/. Diunduh pada tanggal 19 Agustus 2017. 